\title{
Invited review: Further progress is needed in procedures for the biological evaluation of dietary protein quality in pig and poultry feeds
}

\author{
Frank Liebert \\ Chair of Animal Nutrition, University of Göttingen, Kellnerweg 6, 37077 Göttingen, Germany \\ Correspondence to: Frank Liebert (flieber@gwdg.de)
}

Received: 12 April 2017 - Revised: 28 June 2017 - Accepted: 5 July 2017 - Published: 8 August 2017

\begin{abstract}
Recently, biological procedures for feed protein evaluation in pig and poultry diets have been based on the amino acid composition of feed ingredients considering the animal's losses during processes of digestion or total protein utilization in a different manner. Such a development towards individual amino acids (AAs) was inevitable according to the disadvantage of traditional protein quality measures, like biological value (BV) or net protein utilization (NPU), to be non-additive in complex animal diets. In consequence, such measures are generally not suitable for predicting the final protein quality of protein mixtures from the individual protein value of feed ingredients. Otherwise, recent measures of AA disappearance from the small intestine up to the end of the ileum (ileal AA digestibility) also do not provide a true reflection of the biological availability of individual feed AAs independent of the extent of taking into account endogenous AA losses during digestion processes. Sophisticated procedures for protein evaluation are needed considering the AA losses, both during absorption and utilization after absorption. Advantages and limitations of important developments in procedures are discussed. Accordingly, the development of an exponential modelling approach is described (the "Göttingen approach"), which overcomes some of the traditional disadvantages by measuring the individual AA efficiency. Connecting feed protein evaluation, the modelling of quantitative AA requirements, and improved ideal protein concepts offers different fields of application. In addition, as demonstrated by example, the modelling of nitrogen losses per unit protein deposition and the minimizing of this parameter yields a further interesting tool for lowering the nitrogen burden from protein utilization processes. Finally, it is pointed out that traditional laboratory procedures also need to be updated, adapted to current knowledge, and validated according to the increasing hurdles for animal studies from the viewpoint of animal welfare. Modelling is a procedure with the potential to reduce the number of experimental animals significantly. This development needs more attention, higher acceptance, and wider application in the future of protein evaluation.
\end{abstract}

\section{Introduction}

Today, the importance of valid protein evaluation systems in animal nutrition is not a point of dispute. However, the procedures underlay a continuous development over more than 75 years. The implications for the sustainable use of feed protein resources in animal nutrition, which are partly in concurrency with human needs, are clear. Environmental aspects also increase the pressure to further lower the dietary protein supply in animal diets without a decline in the animal's performance data. Consequently, an extended number of in- dispensable amino acids (AA) have become more interesting as a feed additive to compensate for the suboptimal dietary supply of individual AAs. This process yields lower nitrogen $(\mathrm{N})$ loads which have to be eliminated from the animal's metabolism by urea or uric acid synthesis. In summary, all these factors are a driving force for ongoing research on protein evaluation in animal nutrition. The current review aims to summarize the important steps in the development of this important area of nutritional research over decades and also to discuss the advantages and limitations of approaches and draw some conclusions for focusing further research work. 
In contrast to earlier reviews (Bock, 1975; Bergner, 1994), an extended focus on biological protein evaluation (Hackler, 1977) will overcome the excessive view on digestibilityrelated processes in the digestive tract. This current procedure is supported by the general view of Fuller (2012) who pointed out that digestibility is not the only determinant of nutrient bioavailability; an integration of factors is needed for factors that limit the extent of absorption and the availability of AA for metabolism. Despite the well-known difficulties of such an integrated procedure, it will provide the most validated information from a nutritional point of view and consequently also the guideline for the present review.

\section{Important developments}

The starting point of intensified protein research would be expected in the middle of the 19th century, but it seems speculative to name the first scientist who recognized the nutritional importance of $\mathrm{N}$-containing substances in feed or food. An excellent review by Block and Mitchell (1946) indicates that up to the beginning of the 20th century it was believed that only intact proteins were of nutritional value for the consumer. However, several studies applying hydrolyzed proteins provided the experimental background for the current view that protein nutrition is in fact an AA nutrition, and last but not least, that it is necessary to decide between dispensable and indispensable AAs depending on species and age (see Block and Mitchell, 1946).

Up to now, it has been a fundamental principle of biological protein evaluation to relate the effect of a given protein intake to the animal's response as measured by different, but mostly growth-related, criteria. Osborne et al. (1919) have set the starting point by creating the protein efficiency ratio (PER) in experiments with the laboratory rat to define the maximum PER for individual protein sources based on experiments with graded dietary protein supply.

\section{PER $($ protein efficiency ratio $)=$ Body weight gain $:$ Protein intake}

In fact, the observed maximum PER of individual feed proteins differs depending on the dietary protein quality, but the maximum PER is achieved with a different dietary protein supply. In consequence, several later PER applications have modified the original approach through a standardization of protein intake. Block and Mitchell (1946) discussed these procedures in detail and mostly under critical view. However, based on the rather easy way of measuring both the protein intake and the gain response in experimental animals, the PER approach is also currently in use as a complex measure of dietary protein quality, mainly for protein substitution studies in fish nutrition (e.g. Peres and Olivia-Teles, 2005; Slawski et al., 2011; Piccolo et al., 2017) or as response criteria in requirement studies (e.g. Ahmed and Khan, 2004). Several limitations in the procedure are mostly overlooked. In spite of the uncomplicated measure of body weight gain, the age-dependent variation in body nutrient composition is not taken into account. However, the response of this influence factor to derived dietary protein quality is lower in standardized rat growth trials, but not in agricultural animals.

In addition, Eggum et al. (1971, cited by Bock, 1975) proposed a nitrogen efficiency ratio (NER) to eliminate effects resulting from the transfer factor (6.25) for crude protein calculation from analysed nitrogen content on protein quality assessment. In consequence, a more precise distinction between different feed proteins was expected.

NER(nitrogen efficiency ratio $)=\frac{\text { Body weight gain }}{\text { Nitrogen intake }}$

This assumption was not validated in general, and consequently the modification was not widely introduced in animal nutrition.

The recommendation of Mitchell (1924) to evaluate feed proteins based on the biological value (BV) became much more precise by taking into account more physiologically based data, like $\mathrm{N}$ deposition (ND), $\mathrm{N}$ maintenance requirement (NMR), and the true digestibility of the feed protein:

$\mathrm{BV}($ biological value $)=\frac{\mathrm{ND}+\mathrm{NMR}}{\mathrm{N} \text { intake as truly digested }} \times 100$.

In addition to the observed $\mathrm{N}$ deposition (ND) data as response criteria provided by N-balance studies, information about the quantity of endogenous $\mathrm{N}$ losses was required. The nitrogen maintenance requirement (NMR) is a reflection of the $\mathrm{N}$ quantity needed to replace the metabolic (endogenous) $\mathrm{N}$ losses via faeces and urine, respectively. Finally, data about $\mathrm{BV}$ were achieved by relating the sum of $\mathrm{N}$ deposition (ND) and NMR to the uptake of truly digested feed protein as a measure of $\mathrm{N}$ utilization following the process of absorption. Over decades, this procedure dominated the field of feed and food protein evaluation for single-bowl animals. In consequence, based on $\mathrm{N}$-balance studies, fundamental concepts were developed to provide comparable information about the complex protein value of individual feedstuffs or diets, in spite of the fact that the knowledge about protein metabolism and functional properties of individual AAs increased (Lintzel, 1939).

Mitchell and Carman (1924) created a net protein value taking into account protein content, protein digestibility, and $\mathrm{BV}$ as the three important factors for the dietary protein value. The net protein value of an individual protein source was achieved by multiplying these data (Mitchell et al., 1945). Later on, multiplying the coefficient of true protein digestibility and BV provided a useful measure of total utilization or net utilization of a dietary protein (Block and Mitchell, 1946). Accordingly, Bender and Miller (1953a) defined the net protein value (NPV) based on results of the traditional N-balance technique. However, due to an elevated number of $\mathrm{N}$ analyses and a time-consuming procedure, a short rat assay estimating the $\mathrm{N}$ content in the body from a 
strong correlation between body water and whole body nitrogen content (Bender and Miller, 1953b) was later recommended (Miller and Bender, 1955) for assessing net protein utilization (NPU):

$\mathrm{NPU}($ net protein utilization $)=\frac{B-(B k-I k)}{I}$,

where $B$ is the total body $\mathrm{N}$ of the rats on the test protein, $B k$ is the total body $\mathrm{N}$ of the rats on a non-protein diet, $I$ is the $\mathrm{N}$ intake of the test protein group, and $I k$ is the $\mathrm{N}$ intake of the non-protein group.

Expressed as a percentage, the NPU reflects the efficacy of net protein utilization (Miller and Bender, 1955; Bender and Doell, 1957). From the current point of view, the term "net" indicates that a separate non-protein group of rats was utilized to create a measure for metabolic $\mathrm{N}$ losses, which need to be replaced by the dietary protein supply.

Summarizing the expressiveness of both true N digestibility and BV, Lintzel (1941) proposed the term "Physiologischer Nutzwert":

Physiologischer Nutzwert $=\frac{\text { True N digestibility } \times \text { biological value }}{100}$.

A new understanding about protein metabolism led to acceptance that a mixture of absorbed exogenous and endogenous AA from protein catabolism can be utilized to replace the endogenous metabolic losses. Lintzel and Rechenberger (1940) and Gebhardt (1966) established the PNu as a benchmark for evaluating dietary protein quality:

$\mathrm{PNu}($ physiological value of protein $)=\frac{\mathrm{ND}+\mathrm{NMR}}{\mathrm{NI}} \times 100$.

In fact, the application of this formula yields equal results with Lintzel (1941). Additionally, all experimental data were related to the metabolic body weight $\left(\mathrm{BW}_{\mathrm{kg}}^{0.67}\right)$. The sum of ND and NMR was described as N retention (NR) and needs to be distinguished from ND in terminology.

This was the initial situation when Gebhardt (1966) developed the new basic concept of an exponential $\mathrm{N}$ utilization model. $\mathrm{N}$ balance experiments with the laboratory rat and general agreement about the importance of replacing endogenous $\mathrm{N}$ losses in future protein evaluation systems provided the platform. An exponential function conforming to the biological laws of growth (von Bertalanffy, 1951) provided a physiologically well-founded response curve of body $\mathrm{N}$ deposition depending on both the quantity and quality of feed protein intake. A significant driving force for this research was the observed restriction for the application of traditional procedures for complex protein evaluation of individual feedstuffs or mixed diets. Unfortunately, traditional measures, like PER, BV, and NPU, were not independent of the actual level of dietary protein intake (Block and Mitchell, 1946). Each of these parameters was modulated with characteristic course when the dietary protein supply of the same protein was increased or lowered.
In Germany, a special working group on protein evaluation was established to discuss fundamental problems of BV and NPU during the 12th annual meeting of the Society for $\mathrm{Nu}-$ trition Physiology (Gebhardt and Brune, 1960). This was indeed the starting point to improve the reliability of feed protein evaluation. Accordingly, the new concept of Gebhardt (1966) was at first focused on standardization to improve the comparability of protein quality measures. Consequently, the exponential model was developed as a tool to make dietary protein quality parameters independent of $\mathrm{N}$ intake. Due to the common principle of several procedures taking into consideration the cost of $\mathrm{N}$ maintenance metabolism, the common term NPU is subsequently applied for protein quality measures making use of the relation between NR and $\mathrm{N}$ intake (NI):

$\mathrm{NPU}($ net protein utilization $)=\frac{\mathrm{NR}}{\mathrm{NI}} \times 100$.

This application is valid independent of different methods and different adequacy to reflect the real quantitative $\mathrm{N}$ costs for maintenance metabolism. In this context, no distinction is made between $\mathrm{N}$-balance data and the results of comparative slaughter techniques with whole body analyses to quantify ND in the animal. This type of model application is still in use for evaluating the complex protein value of mixed feeds. However, in the meantime the application field of the approach was significantly extended and adapted to recent expectations for protein nutrition research in food-producing animals.

\section{Current applications}

Several reports provide the details of current developments and applications of the basic concept as initiated by Gebhardt (1966) and further developed by Liebert and Gebhardt (1988). Today, the procedure is called the "Göttingen approach" due to further developments over 2 decades at the University of Göttingen (Liebert, 2015; Dorigam et al., 2017; Samadi et al., 2017). However, it will not be possible to outline in detail how the different issues of the current procedure differ from other approaches recently in use. Model-specific parameters as utilized in current applications were justified in earlier and recent publications (e.g. Liebert et al., 2000; Thong and Liebert, 2004a-c; Samadi and Liebert, 2006a, b, 2007a, b, 2008; Liebert and Benkendorff, 2007a, b; Liebert, 2008, 2009, 2015; Liebert and Wecke, 2008; Samadi et al., 2017; Wecke and Liebert, 2009, 2010, 2013; Wecke et al., 2016; Dorigam et al., 2017) and can be condensed as follows:

$\mathrm{NR}=\mathrm{NR}_{\text {max }} T\left(1-e^{-\mathrm{NI} \cdot b}\right)$
$\mathrm{ND}=\mathrm{NR}_{\max } T\left(1-e^{-\mathrm{NI} \cdot b}\right)-\mathrm{NMR}$,

where $\mathrm{NR}$ is daily $\mathrm{N}$ retention (ND+NMR) $\left[\mathrm{mg}\left(\mathrm{BW}_{\mathrm{kg}}^{0.67}\right)^{-1}\right]$, ND is daily $\mathrm{N}$ deposition or $\mathrm{N}$ bal- 


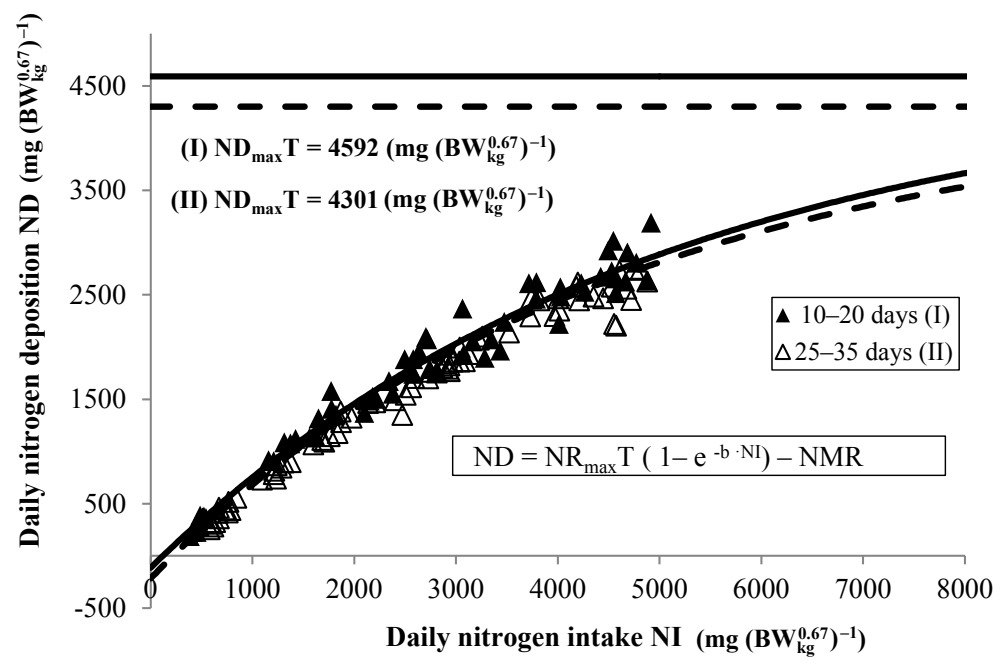

Figure 1. Results of $\mathrm{N}$ rise experiments with growing chickens (Ross 308) depending on age period for estimating the threshold value $\mathrm{ND}_{\max } T$ (Pastor et al., 2013).

ance (NI- NEX $\left.\left[\mathrm{mg}\left(\mathrm{BW}_{\mathrm{kg}}^{0.67}\right)^{-1}\right]\right)$, NI is daily $\mathrm{N}$ intake $\left[\mathrm{mg}\left(\mathrm{BW}_{\mathrm{kg}}^{0.67}\right)^{-1}\right], \quad \mathrm{NEX}$ is daily $\mathrm{N}$ excretion $\left[\mathrm{mg}\left(\mathrm{BW}_{\mathrm{kg}}^{0.67}\right)^{-1}\right], \mathrm{NMR}$ is daily $\mathrm{N}$ maintenance requirement $\left[\mathrm{mg}\left(\mathrm{BW}_{\mathrm{kg}}^{0.67}\right)^{-1}\right], \mathrm{NR}_{\max } T$ is the theoretical maximum for daily $\mathrm{NR}\left[\mathrm{mg}\left(\mathrm{BW}_{\mathrm{kg}}^{0.67}\right)^{-1}\right], \mathrm{ND}_{\max } T=\mathrm{NR}_{\max } T-\mathrm{NMR}$ is the theoretical maximum for daily ND $\left[\mathrm{mg}\left(\mathrm{BW}_{\mathrm{kg}}^{0.67}\right)^{-1}\right], b$ is the slope of the NR curve indicating the dietary protein quality (the slope of the curve for a given protein quality is independent on $\mathrm{NI}$ ), and $e$ is the basic number of the natural logarithm (ln).

The attribute "theoretical" suggests that the threshold values $\left(\mathrm{ND}_{\max } T\right.$ or $\left.\mathrm{NR}_{\max } T\right)$ are generally not in the scope of practical growth performance data but yield an estimate of the genetic potential when each of the limiting factors for maximum growth are eliminated (Samadi and Liebert, 2006a). This is a theoretical situation indeed, but at least not a limiting factor to derive practical data from modelling. Figure 1 gives an example for this application from current studies.

The genetic potential is defined as an unreachable theoretical threshold value of the exponential function and cannot be realized even with an optimized feeding strategy or in ideal environmental conditions. If the ranking of such a threshold value is clear, no problem exists for further model applications. Accordingly, individual amino acid (AA) requirement data are derived for daily protein deposition data in line with practical growth data. The threshold value $\left(\mathrm{ND}_{\max } T\right.$ resp. $\mathrm{NR}_{\max } T$ ) is used only as a model parameter to relate the real rate of deposition to the estimated genetic potential.

A validation of the model parameter $b$ as a measure of dietary protein quality, which is independent of the actual level of protein intake, has been reported in several pig and poultry studies (e.g. Thong and Liebert, 2004a, b, c; Wecke and Liebert, 2009; Farke, 2011; Pastor et al., 2013; Pastor, 2014). According to the basic concept of standardizing NI for valid feed protein evaluation, the model is also currently applied for assessing the dietary protein quality in mixed diets with alternative protein sources making use of a standardized value of NPU (Brede et al., 2016; Dietz et al., 2016; Dietz and Liebert, 2017; Neumann et al., 2017). More diversified applications of such an important tool could help to overcome misleading conclusions about the reality of distinctions in feed protein value between protein sources (Neumann et al., 2017).

\subsection{Characterization of developing the genetic potential}

As already discussed, the estimation of $\mathrm{ND}_{\max } T$ is required as a threshold value for basic applications of the exponential model, but as a given percentage of the theoretical threshold value $\mathrm{ND}_{\max } T$ real performance data are utilized to derive AA requirement data depending on graded aimed animal performance (e.g. Wecke et al., 2016; Samadi et al., 2017). However, also from the viewpoint of animal breeding, the observed $\mathrm{ND}_{\max } T$ data are of interest because they provide additional information about breeding success. An example for this application with growing chickens is demonstrated in Fig. 1.

The threshold value of the exponential function $\left(\mathrm{ND}_{\max } T\right)$ is estimated by statistical application of the LevenbergMarquardt algorithm (Marquardt, 1963) as reported elsewhere (e.g. Samadi and Liebert, 2008; Wecke and Liebert, 2009; Pastor et al., 2013). The applicability of the procedure was also demonstrated in fish nutrition (Liebert et al., 2006) and utilized for AA requirement studies in Oreochromis niloticus (Liebert and Benkendorff, 2007a, b; Liebert, 2009). 
Table 4. Example for modelling lysine (Lys) requirement data during the starter and grower periods of male meat-type chickens (Ross 308) depending on graded daily protein deposition, different in-feed efficiency of Lys, and predicted daily feed intake (Wecke et al., 2016).

\begin{tabular}{lrrrrrrrrrrr}
\hline \multicolumn{1}{c}{ Starter period (d10-20, mean BW 600 g) } \\
\hline PD $\left(\mathrm{g} \mathrm{day}^{-1}\right)$ \\
BWG $\left(\mathrm{g} \mathrm{day}^{-1}\right)$
\end{tabular}

Lys content needed in the starter diet $(\%)$

\begin{tabular}{llllllllll}
\hline FI $\left(\mathrm{g} \mathrm{day}^{-1}\right)$ & & & & & & & & \\
70 & 0.91 & 0.96 & 1.02 & 1.06 & 1.12 & 1.18 & 1.22 & 1.29 & 1.36 \\
80 & 0.80 & 0.84 & 0.89 & 0.93 & 0.98 & 1.03 & 1.07 & 1.13 & 1.19 \\
90 & 0.71 & 0.75 & 0.79 & 0.82 & 0.87 & 0.92 & 0.95 & 1.00 & 1.06 \\
\hline
\end{tabular}

\begin{tabular}{|c|c|c|c|c|c|c|c|c|c|}
\hline \multicolumn{10}{|c|}{ Grower period (d25-35, mean BW $1800 \mathrm{~g}$ ) } \\
\hline \multirow{3}{*}{$\begin{array}{l}\mathrm{PD}\left(\mathrm{g} \mathrm{d}^{-1}\right) \\
\mathrm{BWG}\left(\mathrm{g} \mathrm{day}^{-1}\right)\end{array}$} & \multirow{2}{*}{\multicolumn{3}{|c|}{$\begin{array}{l}15 \\
91\end{array}$}} & \multirow{2}{*}{\multicolumn{3}{|c|}{$\begin{array}{l}16.5 \\
100\end{array}$}} & \multirow{2}{*}{\multicolumn{3}{|c|}{$\begin{array}{c}18 \\
109\end{array}$}} \\
\hline & & & & & & & & & \\
\hline & (1) & (2) & (3) & (1) & (2) & (3) & (1) & (2) & (3) \\
\hline$b c_{\text {Lys }}^{-1}$ & 64.5 & 61.3 & 58.1 & 64.5 & 61.3 & 58.1 & 64.5 & 61.3 & 58.1 \\
\hline \multirow{2}{*}{$\begin{array}{l}\text { Lys required } \\
\left(\mathrm{mg}\left(\mathrm{BW}_{\mathrm{kg}}^{0.67}\right)^{-1} \mathrm{day}^{-1}\right) \\
\left(\mathrm{mg} \mathrm{day}^{-1}\right)\end{array}$} & 753 & 793 & 837 & 858 & 903 & 953 & 975 & 1026 & 1083 \\
\hline & 1117 & 1175 & 1241 & 1272 & 1339 & 1413 & 1446 & 1522 & 1606 \\
\hline \multicolumn{10}{|c|}{ Lys content needed in the grower diet (\%) } \\
\hline \multicolumn{10}{|l|}{$\mathrm{FI}\left(\mathrm{g}_{\text {day }^{-1}}\right)$} \\
\hline 150 & 0.74 & 0.78 & 0.83 & 0.85 & 0.89 & 0.94 & 0.96 & 1.02 & 1.07 \\
\hline 170 & 0.66 & 0.69 & 0.73 & 0.75 & 0.79 & 0.83 & 0.85 & 0.90 & 0.95 \\
\hline 190 & 0.59 & 0.62 & 0.65 & 0.67 & 0.70 & 0.74 & 0.76 & 0.80 & 0.84 \\
\hline
\end{tabular}

PD is daily protein deposition ( $\mathrm{N}$ deposition $\times 6.25$ ), BWG is daily body weight gain (crude protein content in $\mathrm{BWG} 16.5 \%$ ), $b c_{\mathrm{Lys}}^{-1}$ is lysine efficiency: (1) as observed, (2) $5 \%$ lower as observed, (3) $10 \%$ lower as observed. Lys supply required is the lysine requirement for targeted PD. FI is daily feed intake.

can be transformed into Eq. (4) when taking into account the concentration of LAA in the feed protein:

$\mathrm{LAAI}=\left[\ln \mathrm{NR}_{\max } T-\ln \left(\mathrm{NR}_{\max } T-\mathrm{NR}\right)\right]: 16 b c^{-1}$,

where LAAI is the daily intake of the LAA $\left[\mathrm{mg}\left(\mathrm{BW}_{\mathrm{kg}}^{0.67}\right)^{-1}\right]$, $c$ is the concentration of the LAA in the feed protein [g $16 \mathrm{gN}^{-1}$ ], and $b c^{-1}$ is the observed dietary efficiency of the LAA.

Equation (4) is widely applied for assessing quantitative AA requirement data in both earlier (Liebert et al., 1987; Liebert and Gebhardt, 1988; Thong and Liebert, 2004ac; Samadi and Liebert, 2006a, b, 2007a, b; Liebert, 2009; Wecke and Liebert, 2009, 2010) and recent studies (Pastor et al., 2013; Wecke and Liebert, 2013; Khan et al., 2015; Dorigam et al., 2017; Samadi et al., 2017). An important precondition for validated conclusions is that experimental data are available which describe the NR or ND response to a defined LAAI at a specific level of dietary efficiency of the LAA, as reflected by the model parameter $\left(b c^{-1}\right)$. The existing relationship between the aimed daily ND, graded dietary efficiency of the AA under study, and required LAAI in context with the expected level of feed intake is demonstrated in Table 4.

It is shown by example that the finally recommended infeed concentration of lysine is under the influence of both animal factors and feed factors, which need to be taken into account for the validity of the recommended in-feed AA concentrations. The real feed intake depends on age, gender, and genotype, but environmental variables, like climate, are also generally underestimated influence factors. More attention has to be given to the modulating effects of such zootechnical factors. If not, it cannot be expected that requirement studies 
Table 5. Optimal dietary ratios for individual amino acids as related to lysine; results of a meta-analysis (Wecke and Liebert, 2013).

\begin{tabular}{lcrc}
\hline & $N^{*}$ & Average & SD \\
\hline Lysine & 26 & 100 & 0 \\
Methionine & 22 & 40 & 4 \\
Methionine + cysteine & 24 & 74 & 2 \\
Threonine & 24 & 66 & 3 \\
Tryptophan & 22 & 16 & 1 \\
Arginine & 25 & 105 & 4 \\
Histidine & 12 & 34 & 4 \\
Isoleucine & 24 & 69 & 4 \\
Valine & 21 & 80 & 4 \\
Leucine & 12 & 110 & 6 \\
Phenylalanine & 8 & 66 & 3 \\
Phenylalanine + tyrosine & 9 & 120 & 7 \\
\hline
\end{tabular}

${ }^{*}$ Number of references involved.

under controlled conditions will yield generalizable requirement data. These factors are also important when traditional dose-response experiments are applied in AA requirement studies, but they are insufficiently taken into account as currently demonstrated by Samadi et al. (2017).

Dose-response experiments are widely applied when the efficacy of supplemented AAs is under study. However, misleading efficacy for L- and DL-methionine isomers was concluded (Shen et al., 2014) when both the basic preconditions for the application of statistical procedures and factors as discussed above are ignored. In contrast, applications of the "Göttingen approach" yielded similar methionine efficiency for both of the isomers in chicken studies (Liebert et al., 2015) in agreement with recent reports (e.g. Htoo and Morales, 2016). This example underlines the importance of a verified experimental design and validated physiologically based statistical procedures for generalized conclusions about the efficacy of supplemented feed AAs.

\subsection{Improvements on the ideal protein concept}

One approach to realize the high efficiency of protein utilization in agricultural animals is the earlier concept to recommend an ideal dietary protein composition for diet formulation (Almquist and Grau, 1944; Oser, 1951; Dean and Scott, 1965). Later on, the dietary ideal amino acid ratio (IAAR) was introduced by Cole et al. (1980) and taken over by the British ARC (1981) for pig nutrition.

Currently, the IAAR concept is widely accepted in pig and poultry nutrition (e.g. Baker, 2003; Wecke and Liebert, 2013; Wecke et al., 2016). The individual indispensable AAs have to be related to a reference AA, mostly lysine (Lys), which is almost exclusively utilized for body protein deposition in growing animals. In addition to the quantitative AA requirement data (Table 4), applications of the "Göttingen approach" may also contribute to improving the IAAR both in-
Table 6. IAAR of growing meat-type chickens as derived by directly relating observed amino acid efficiency data according to Eq. (5) (Wecke and Liebert, 2013).

\begin{tabular}{lrr}
\hline Amino acid & Starter & Grower \\
\hline Lysine & 100 & 100 \\
Threonine & 60 & 62 \\
Tryptophan & 19 & 17 \\
Arginine & 105 & 105 \\
Isoleucine & 55 & 65 \\
Valine & 63 & 79 \\
\hline
\end{tabular}

directly via individual AA requirements and directly by relating the observed AA efficiency data (model parameter $b c^{-1}$ ) as reported recently (Samadi and Liebert, 2008; Pastor et al., 2013; Wecke and Liebert, 2013; Khan et al., 2015; Liebert, 2015). According to Samadi and Liebert (2008), the reciprocal relationship between Lys efficiency (as reference AA) and the observed efficiency of the individual LAA under study is utilized to derive optimal dietary AA ratios (Eq. 5):

$\mathrm{IAAR}=b c_{\mathrm{LYS}}^{-1}: b c_{\mathrm{LAA}}^{-1}$.

As already mentioned, model parameter $b$ linearly depends on LAA concentration $(c)$ in the protein, and the slope $\left(b c^{-1}\right)$ is an expression of AA efficiency by summarizing both digestibility and post-absorptive utilization of the LAA in general agreement with Lintzel (1941). In addition, the order of observed AA efficiency data from the individual AA under study is indirectly related to the specific physiological AA requirement per unit of protein deposition. From this point of view, both feed factors and animal factors are involved when comparisons are made at the level of observed AA efficiency data. As pointed out by Wecke et al. (2016), the reliability of measured AA efficiency data for the reference AA Lys is a fundamental precondition for such applications. The summarized results of a meta-analysis are given in Table 5 .

Actually, the complete information about the IAAR of indispensable AAs with the "Göttingen approach" is not available. A summary of current results based on applications of Eq. (5) is given in Table 6.

According to the fact that both feed and animal factors modulate the observed AA efficiency data, further studies have to enlighten their individual quantitative importance. The sulfur-containing AAs methionine and cysteine are the focus of ongoing experiments.

\section{$4 \quad$ Future applications}

Eggum and Christensen (1974) basically demonstrated the additivity of the protein digestibility data in a mixture in relation to the protein digestibility of individual ingredients. However, the missing additivity of traditional protein quality parameters for individual feed proteins, as discussed above, 
is the main limitation to making use of these parameters in optimizing animal feeds. Consequently, the further development of protein quality evaluation systems had to be founded on evaluation of individual AAs. At least the specific contribution of the individual feed proteins is added, and in summary it yields the AA content of the final diet.

Over many years, only the chemically analysed total AA content was utilized in feed formulation for monogastric agricultural animals. A next step to come closer to the utilization process in the animal was focused on AA digestibility as measured at the end of the digestive tract (digestible AA). However, increasing knowledge about the significance of microbial processes in the digestive tract, namely in the post-ileal sections of the intestine, led to procedures for measuring the individual AA digestibility up to the end of the small intestine (e.g. Low, 1980; Sauer and Ozimek, 1986; Van Leeuwen et al., 1987; Lemme et al., 2004; Stein et al., 2007). Since Low (1980), it is generally accepted that ileal measurement is preferred to the faecal method in simplestomached animals when the digestion and absorption of AAs is to be evaluated. However, ileal digestibility may be expressed as apparent, standardized, or true digestibility. Endogenous losses are separated into basal and specific losses, and specific losses are induced by feed ingredient characteristics, like fiber content, type of fiber, and anti-nutritional factors (Stein et al., 2007). In consequence, a high modulation of endogenous AA losses can be expected but is sufficiently taken into account only in part. Currently, only basal AA losses are estimated depending on feed intake and providing a standardized ileal digestibility. In consequence, a database for standardized AA digestibility in pig and poultry was created (e.g. Evonik, 2016). The advantage is that standardized AA digestibility data are more likely to be taken into account in mixed diets compared with apparent ones (Stein et al., 2005). In this context, it is important to note again that standardized ileal AA digestibility only means that basal endogenous AA losses are considered. In addition, several proposals were made to standardize the experimental procedures as a whole, namely the section of the small intestine taken for chyme sampling in poultry studies (e.g. Kluth and Rodehutscord, 2006, 2009). Generally, for an improved validity of the observed AA digestibility data, a standard type of experiment is required taking into account more than the procedure of chyme sampling (Ravindran et al., 2017).

However, according to Stein et al. (2007) all measures of AA digestibility are generally based on the disappearance of AA from the digestive tract only. These measures do not reflect the net breakdown or synthesis of AA in the intestinal lumen and the absorption of chemical forms, like Maillard reaction products (Maillard, 1912) with Lys, which are precluded from metabolic utilization for protein synthesis. The $\varepsilon$-amino group of Lys is the primary target for an attack by reducing carbohydrates, and up to $70 \%$ of the Lys residues of a protein are reactive and can be damaged depending on the factors time and temperature (Finot et al., 1977). Previ- ous work with growing pigs has demonstrated that the ileal digestibility assay overestimates the availability of Lys, but also threonine, methionine, and tryptophan in heat-processed proteins (Batterham et al., 1990; Batterham, 1992). It appears that a considerable portion of these amino acids is absorbed but inefficiently utilized. In the case of isoleucine, it was indicated that ileal digestibility more closely reflected the proportion of the AA that can be utilized by the pig (Batterham and Andersen, 1994). Consequently, in the case of heat-processed feed proteins it cannot be expected that measures of the ileal AA digestibility are generally a valid indicator of the available AA supply in pigs. According to Carpenter (1973), reactive amino groups can also be provided by arginine and histidine, indicating that Lys represents not the only problem but the most important one.

In addition, microbial fermentation in the small intestine may also contribute to the synthesis and catabolism of AA, and in consequence to discrepancies between ileal AA digestibility data and AA bioavailability, which include AA utilization following the absorption process (Fuller, 2003).

Summarizing these aspects with a focus on future developments in feed protein evaluation, it cannot be accepted to commit only to ileal AA digestibility. In addition, strengthened animal protection laws are limiting surgery techniques to make use of fistulated pigs or caecectomized birds. In consequence, it remains doubtful whether the needed database update can be sufficiently ensured by in vivo studies. The applications of traditional procedures, like feeding experiments and digestibility and balance studies, are also relevant from the viewpoint of animal welfare when metabolism cages restrict activities, movement, and inter-individual contact. Consequently, the demand from the viewpoint of animal science needs to be stated for further scientific development (Committee for Requirement Standards of the Society of Nutrition Physiology, 2017).

Unfortunately, measures of AA bioavailability based on the response of growth parameters or body protein deposition, which can sort below the maximum permissible load from the viewpoint of animal protection, are generally restricted to investigating the LAA under study. In consequence, both the procedure AA efficiency ("Göttingen approach") and each of the other techniques to measure AA bioavailability cannot provide an enlarged database usable for feed protein evaluation systems. The only way out for routine protein evaluation is to create more in vitro techniques as proposed earlier (e.g. Savoie and Gauthier, 1986; Galibois et al., 1989; Huang et al., 2000; Van Kempen and Bodin, 1998; Boisen, 2000).

In addition, analytical procedures for the evaluation of AA bioavailability, extensively starting with Carpenter (1960, 1973) and Booth (1971), may yield improved information when they are further developed (e.g. Hurrell et al., 1979; Nordheim and Coon, 1984). The use of the rat as a model animal for growing pigs was discussed by Rutherford and Moughan (2003). The potential for such alternative proce- 
dures can be seen when they are adapted to current knowledge and validated in vivo. However, systemic developments in this field are unfortunately missing.

The further potential of the modelling procedure as presented consists of estimating $\mathrm{N}$ losses during protein conversion processes in the animal, depending on both feed factors and animal factors (Dänicke and Liebert, 1992; Liebert, 1996; Liebert and Wecke, 2010, 2012). Such a tool has the potential to be developed into a physiologically based estimate for $\mathrm{N}$ excretion (NEX) per unit ND (NEX: ND) deposition depending on the aimed animal's performance (ND) and the available feed protein in terms of quantity and quality. An example for this application is given in Fig. 2.

Clearly, the lowest ratio NEX: ND in a $50 \mathrm{~kg}$ growing pig was achieved at approximately $2500 \mathrm{mg} \mathrm{NI}$ per $\mathrm{BW}_{\mathrm{kg}}^{0.67}$, corresponding to $215 \mathrm{~g}$ of daily crude protein intake and providing $115 \mathrm{~g}$ of daily protein deposition. It is indicated that both a lower and higher protein supply create a higher ratio NEX : ND. However, the course of the response curve is also dependent on the age period and the dietary protein quality. In consequence, the better the protein quality, the lower the required protein supply, and the ratio NEX : ND will further decline. In addition, requirement recommendations for individual AAs can be derived for an optimal level to make use of the $\mathrm{ND}_{\max } T$ depending on genotype and corresponding to a minimized NEX:ND. Such a sophisticated application of the modelling procedure needs an enlarged database for model parameter $\mathrm{ND}_{\max } T$ (e.g. Nörenberg, 1987; Farke, 2011; Wecke and Liebert, 2009; Khan et al., 2015) and observed individual AA efficiency data in mixed diets with and ingredient composition near practical feeding conditions (e.g. Liebert, 2008; Samadi and Liebert, 2008; Wecke and Liebert, 2009, 2010, 2013; Wecke et al., 2016; Pastor et al., 2013; Samadi et al., 2017), which may reflect the real variation in this model parameter in common feedstuffs.

Finally, modelling protein metabolism with the physiologically based "Göttingen approach" lays the foundations for the most important applications in the field of current protein evaluation for simple-stomached growing animals:

- defining the genotype in terms of the theoretical potential for $\mathrm{N}$ deposition $\left(\mathrm{ND}_{\max } T\right)$;

- assessing feed protein value based on observed efficiency of the limiting AA;

- concluding AA requirements taking into account graded dietary AA efficiency;

- modelling AA requirements depending on the aimed level of performance (percent of $\mathrm{ND}_{\max } T$ );

- evaluating the efficacy of supplemented AAs as related to protein-bound AAs or different isomers or analogues of the added-feed AAs;

- and modelling the $\mathrm{N}$ losses from the $\mathrm{N}$ utilization process in terms of minimized $\mathrm{N}$ excretion per unit ND.

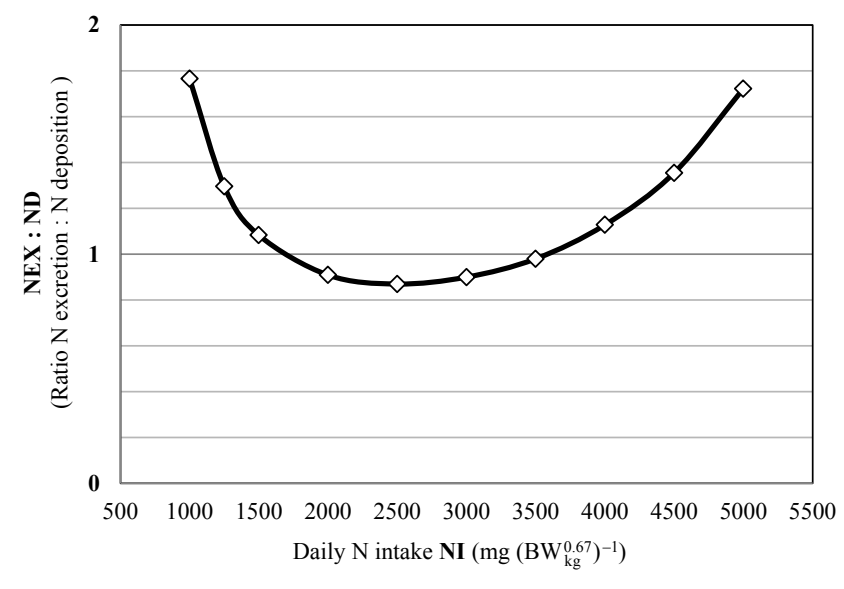

Figure 2. Course of $\mathrm{N}$ excretion per unit $\mathrm{N}$ deposition (NEX : ND) as derived from $\mathrm{N}$ balance data and exponential function of NEX dependent on $\mathrm{N}$ intake in growing pigs of $50 \mathrm{~kg} \mathrm{BW}$ (Wecke and Liebert, 2009).

Greater acceptance by both scientific societies and applied research groups is needed to make use of each type of complex modelling procedure. It would be desirable to compensate for the upcoming limitation on in vivo studies due to increasing standards for animal welfare and animal protection through the extended application of physiologically based modelling, also in the field of protein evaluation for pig and poultry diets.

Data availability. Data are available in the original papers cited.

Competing interests. The author declares no conflict of interest.

Edited by: Manfred Mielenz

Reviewed by: two anonymous referees

\section{References}

Ahmed, I. and Khan, M. A.: Dietary lysine requirement of fingerling Indian major carp, Cirrhinus mrigala (Hamilton), Aquaculture, 235, 499-511, 2004.

Almquist, H. J. and Grau, C. R.: The Amino Acid Requirement of the Chick, J. Nutr., 28, 325-331, 1944.

ARC - Agricultural Research Council: The Nutrient Requirement of Pigs, Commonwealth Agricultural Bureaux, Slough, UK, 1981.

Baker, D. H.: Ideal Amino Acid Patterns for Broiler Chicks, in: Amino Acids in Animal Nutrition, 2nd Edn., edited by: D'Mello, J. P. F., CAB International, Wallingford, Oxon, UK, 223-235, 2003.

Batterham, E. S.: Availability and utilization of amino acids for growing pigs, Nutr. Res. Rev., 5, 1-18, 1992.

Batterham, E. S. and Andersen, L. M.: Utilization of ileal digestible amino acids by growing pigs: isoleucine, Br. J. Nutr., 71, 531541, 1994. 
Batterham, E. S., Andersen, L. M., Baigent, D. R., Beech, S. A., and Elliot, R.: Utilization of ileal digestible amino acids by pigs: lysine, Br. J. Nutr., 64, 679-690, 1990.

Bender, A. E. and Doell, B. H.: Note on the determination of net protein utilization by carcass analysis, Br. J. Nutr., 11, 138-139, 1957.

Bender, A. E. and Miller, D. S.: A new brief method of estimating net protein value, Biochem. J., 53, vii, 1953a.

Bender, A. E. and Miller, D. S.: Constancy of the $\mathrm{N} / \mathrm{H}_{2} \mathrm{O}$ ratio of the rat and its use in the determination of the net protein value, Biochem. J., 53, vii-viii, 1953b.

Bergner, H.: Ermittlung der Eiweißqualität von Nahrungs- und Futtermitteln, Arch. Anim. Nutr., 45, 293-332, 1994.

Block, R. J. and Mitchell, H. H.: The correlation of the amino acid composition of proteins with their nutritive value, Nutr. Abstr. Rev., 16, 249-278, 1946.

Bock, H.-D.: Methoden zur Beurteilung der Proteinqualität von Nahrungs- und Futtermitteln, Fortschrittsberichte für die Landwirtschaft und Nahrungsgüterwirtschaft, 13, 1-67, 1975.

Boisen, S.: In vitro digestibility methods: history and specific approaches, in: New developments in feed evaluation, edited by: Moughan, P. J., Verstegen, M. W. A., and Visscher, M., CABI, Wageningen, 153-168, 2000.

Booth, V. H.: Problems in the determination of FDNB-available lysine, J. Sci. Food Agric., 22, 658-666, 1971.

Brede, A., Neumann, C., Velten, S., and Liebert, F.: Evaluation of Hermetia illucens and Spirulina platensis proteins in semisynthetic diets for the laboratory rat, Proc. Soc. Nutr. Physiol., 25, 31, 2016.

Carpenter, K. J.: The estimation of the available lysine in animalprotein foods, Biochem. J., 77, 604-610, 1960.

Carpenter, K. J.: Damage to lysine in food processing: its measurement and its significance, Nutr. Abstr. Rev., 43, 424-451, 1973.

Cole, D. J. A., Yen, H. T., and Lewis, D.: The Lysine Requirements of Growing and Finishing Pigs - The Concept of an Ideal Protein, in: Proceedings of the 3rd International Symposium on Protein Metabolism and Nutrition, Vol. II, edited by: Oslage, H. J. and Rohr, K., EAAP, Braunschweig, Germany, 658-668, 1980.

Committee for Requirement Standards of the Society of Nutrition Physiology: Stellungnahme zur Unerlässlichkeit von Tierversuchen und zur Eignung von Ersatzmethoden in der Tierernährungsforschung, Proc. Soc. Nutr. Physiol., 26, 218-224, 2017.

Dänicke, S. und Liebert, F.: Modellierung des Wachstums und der N-Ausscheidung wachsender Masthähnchen aufder Grundlage des Konzeptes wirksamer Aminosäure, Proc. Int. Tagung Schweine- und Geflügelernährung, Halle, 17-24, 1992.

Dean, W. F. and Scott, H. M.: The Development of an Amino Acid Reference Diet for the Early Growth of Chicks, Poult. Sci., 44, 803-808, 1965.

Dietz, C. and Liebert, F.: Insect protein in aquafeed - effect of substituting soy protein on protein quality of Tilapia feed, Proc. Soc. Nutr. Physiol., 26, 147, 2017.

Dietz, C., Liebert, F. and Winter, B.: Protein hydrolysates from animal by-products as sustainable protein source. I: Effect of thermal hydrolysis and origin of basic material on protein quality, Proc. Soc. Nutr. Physiol., 25, 124, 2016.

Dorigam, J., Sakomura, N., and Liebert, F.: Modelling of lysine requirement in broiler breeder hens based on daily nitrogen reten- tion and efficiency of dietary lysine utilization, Anim. Feed Sci. Technol., 226, 29-38, 2017.

Eggum, B. O. and Christensen, K. D.: Protein digestibility of a feed mixture in relation to the protein digestibility of individual protein components, Br. J. Nutr., 31, 213-218, 1974.

Evonik: AMINODat ${ }^{\circledR} 5.0$ - Animal nutritionist's information edge, in: book I and II, Evonik Nutrition \& Care GmbH, Hanau, Wolfgang, 2016.

Farke, J.: Studien zur Aminosäurenwirksamkeit beim Mastgeflügel unter spezifischer Betrachtung der schwefelhaltigen Aminosäuren, Diss. Univ. Göttingen, 199 pp., http://webdoc. sub.gwdg.de/diss/2011/farke/farke.pdf (last access: Augst 2017), 2011.

Finot, P. A., Bujard, E., and Arnaud, M.: in: Protein cross-linking Nutritional and medical consequences, edited by: Friedman, M., Plenum Press, New York, London, 51-71, 1977.

Fuller, M.: AA bioavailability - A brief history, in: Vol. 1, Proc. 9th Int. Symp. on Digestive Physiology in Pigs, edited by: Ball, R. O., Univ. Alberta, Canada, 183-198, 2003.

Fuller, M.: Determination of protein and amino acid digestibility in foods including implications of gut microbial amino acid synthesis, Br. J. Nutr., 108, S238-S248, 2012.

Galibois, I., Savoie, L., Simoes Nunes, C., and Rerat, A.: Relation between in vitro and in vivo assessment of amino acid availability, Reprod. Nutr. Dev., 29, 495-507, 1989.

Gebhardt, G.: Die Bewertung der Eiweißqualität von Nahrungs- und Futtermitteln mit Hilfe des N-Bilanzversuches, in: Vergleichende Ernährungslehre des Menschen und seiner Haustiere, edited by: Hock, A., Fischer Verl., Jena, 323-348, 1966.

Gebhardt, G.: Parameter des N-Stoffwechsels und Wachstumsgesetzmäßigkeiten, Math.-Nat. wiss. R. 22, Wiss. Z. Karl-MarxUniversität Leipzig, Leipzig, 201-213, 1973.

Gebhardt, G. and Brune, H.: 12. Tagung der Gesellschaft für Ernährungsphysiologie der Haustiere, Arbeitskreis für Eiweißbewertung, Z. Tierphysiol. Tierernähr. Futtermittelkd., 15, 308320, 1960.

Gous, R. M. and Morris, T. R.: Evaluation of a diet dilution technique for measuring the response of broiler chickens to increasing concentrations of lysine, Br. Poult. Sci., 26, 147-161, 1985.

Hackler, L. R.: Methods of measuring protein quality: A review of bioassay procedures, Cereal Chem., 54, 984-995, 1977.

Htoo, J. K. and Morales, J.: Bioavailability of 1-methionine relative to dl-methionine as a methionine source for weaned pigs, J. Anim. Sci., 94, 249-252, 2016.

Huang, R.-L., Tan, Z.-L., Xing, T.-X., Pan, Y.-F., and Li, T.-J.: An in vitro method for the estimation of ileal crude protein and amino acid digestibility using the dialysis tubing for pig feedstuffs, Anim. Feed Sci. Technol., 88, 79-89, 2000.

Hurrel, R. F., Lerman, P., and Carpenter, K. J.: Reactive lysine in foodstuffs as measured by a rapid dye-binding procedure, J. Food Sci., 44, 1221-1231, 1979.

Khan, D. R., Wecke, C., Sharifi, A. R., and Liebert, F.: Evaluating the age dependent potential for protein deposition in naked neck meat type chicken, Animals, 5, 56-70, 2015.

Kluth, H. and Rodehutscord, M.: Comparison of amino acid digestibility in broiler chickens, turkeys and Pekin ducks, Poult. Sci., 85, 1953-1960, 2006. 
Kluth, H. and Rodehutscord, M.: Standardisierte Futterbewertung auf der Basis der Aminosäurenverdaulichkeit beim Geflügel, Übers. Tierernährg., 37, 1-26, 2009.

Lemme, A., Ravindran, V., and Bryden, W. L.: Ileal digestibility of amino acids in feed ingredients for broilers, World's Poult. Sci. J., 60, 423-437, 2004.

Liebert, F.: Methodische Untersuchungen zur Beurteilung von Lysinverwertungskennzahlen von Schweinen nach extremen Veränderungen von Proteinmenge und -zusammensetzung, Arch. Anim. Nutr., 48, 319-327, 1995.

Liebert, F.: Level of protein deposition and N-excretion:Ndeposition ratio in the growing pig and chicken, in: Proc. 7th Int. Symp. Protein metabolism and nutrition, EAAP publ. no. 81, edited by: Nunes, A. F., Portugal, A. V., Costa, J. P., and Ribeiro, J. R., Santarèm, Portugal, p. 397, 1996.

Liebert, F.: Modelling of protein metabolism yields amino acid requirements dependent on dietary amino acid efficiency, growth response, genotype and age of growing chicken, Avian Biol. Res., 1, 101-110, 2008.

Liebert, F.: Amino acid requirement studies in Orechromis niloticus by application of principles of the diet dilution technique, J. Anim. Physiol. Anim. Nutr., 93, 787-793, 2009.

Liebert, F.: Basics and applications of an exponential nitrogen utilization model ("Goettingen approach") for assessing amino acid requirements in growing pigs and meat type chickens based on dietary amino acid efficiency, in: Nutritional Modelling for Pigs and Poultry, edited by: Sakomura, N. K., Gous, R. M., Kyriasakis, I., and Hauschild, L., CABI Publishing, Wallingford, 73$87,2015$.

Liebert, F. and Benkendorff, K.: Modeling lysine requirements of Oreochromis niloticus due to principles of the diet dilution technique, Aquaculture, 267, 100-110, 2007a.

Liebert, F. and Benkendorff, K.: Modelling of threonine and methionine requirements of Oreochromis niloticus due to principles of the diet dilution technique, Aquacult. Nutr., 13, 397-406, $2007 \mathrm{~b}$.

Liebert, F. and Gebhardt, G.: Ergebnisse zur Wirksamkeit und zum Bedarf an ausgewählten Aminosäuren beim wachsenden weiblichen Schwein. 6. Mitt.: Zusammenfassende Diskussion und Wertung sowie Anwendungsempfehlungen zur vorgestellten Methode, Arch. Anim. Nutr., 38, 453-462, 1988.

Liebert, F. and Wecke, C.: Models for further developing the evaluation of protein and amino acids as well as for predicting performance from energy and amino acids intake, in: Recommendations for the Supply of Energy and Nutrients to Pigs, edited by: Staudacher, W., DLG-Verlag, Frankfurt am Main, 219-230, 2008.

Liebert, F. and Wecke, C.: Nitrogen losses per unit of nitrogen deposition as derived from modelling of protein utilization depending on dietary protein quality parameters and age of growing barrows, in: Proc. 3rd Int. Symp. on Energy and Protein Metabolism and Nutrition, Parma, Italy, EAAP publ. no. 127, edited by: Matteo Crovetto, G., Acadademic Publishers, Wageningen, 443-444, 2010.

Liebert, F. und Wecke, C.: Zur Modellierung von NStoffwechselparametern als Basis für die Bewertung der Nachhaltigkeit von Ausschöpfungsstrategien für Wachstumspotenziale bei Masthähnchen und Mastschweinen, VDLUFA-Schriftenreihe 68, VDLUFA-Verlag Darmstadt, 749-755, 2012.
Liebert, F., Le Khac, H., and Gebhardt, G.: Ergebnisse zur Wirksamkeit und zum Bedarf an ausgewählten Aminosäuren beim wachsenden weiblichen Schwein. 4. Mitt.: Kombinationen von Proteinträgern mit Lysin-, Methionin/Zystin- bzw. Threoninlimitanz. Arch. Anim. Nutr., 37, 559-568, 1987.

Liebert, F., Rimbach, M., and Peisker, M.: Model for estimation of amino acid utilization and its requirement in growing animals, Proc. Aust. Poult. Sci. Symp., 12, 88-92, 2000.

Liebert, F., Sünder, A., and Mohamed, K.: Assessment of nitrogen maintenance requirement and potential for protein deposition in juvenile Tilapia genotypes by application of an exponential nitrogen utilization model, Aquaculture, 261, 1346-1355, 2006.

Liebert, F., Wecke, C., and Sünder, A.: Besteht Korrekturbedarf bei der optimalen Versorgung von Masthähnchen mit schwefelhaltigen Aminosäuren? (Invited review), in: Proc. 13. Tag. Schweineund Geflügelernährung, Wittenberg, 32-39, 2015.

Lintzel, W.: Über einige neue Gesichtspunkte und Möglichkeiten der Erforschung des Eiweißstoffwechsels der landwirtschaftlichen Nutztiere, Z. Tierernähr. Futtermittelkd., 2, 32-44, 1939.

Lintzel, W.: Über den Nährwert des Eiweißes der Speisepilze, Biochem. Z., 308, 413-419, 1941.

Lintzel, W. and Rechenberger, J.: Experimentelle Studien zur Theorie des Eiweißstoffwechsels. III. Mitt. Die eiweißsparende Wirkung unvollständiger Eiweiße (Zein und Gelatine) beim Menschen, Biochem. Z., 304, 214-222, 1940.

Low, A. G.: Nutrient absorption in pigs, J. Sci. Food Agric., 31, 1087-1130, 1980.

Maillard, L. C.: Action of amino acids on sugars. Formation of melanoidins in a methodical way, Compt. Rend., 154, 66-68, 1912.

Marquardt, D. W.: An algorithm for least squares estimation of nonlinear parameters, J. Soc. Ind. Appl. Math., 11, 431-441, 1963.

Miller, D. S. and Bender, A. E.: The determination of the net utilization of proteins by a shortened method, Br. J. Nutr., 9, 382-388, 1955.

Mitchell, H. H.: A method of determining the biological value of protein, J. Biol. Chem., 58, 873-903, 1924.

Mitchell, H. H. and Carman, G. G.: The biological value for maintenance and growth of the proteins of whole wheat, eggs, and pork, J. Biol. Chem., 60, 613-620, 1924.

Mitchell, H. H., Hamilton, T. S., and Beadles, J. R.: The importance of commercial processing for the protein value of food products, J. Nutr., 29, 13-25, 1945.

Neumann, C., Velten, S., Kubitza, D., and Liebert, F.: Protein quality of chicken diets with complete substitution of soybean meal by insect meal (Hermetia illucens) or algae meal (Spirulina platensis) and graded fortification of dietary amino acid supply, Proc. Soc. Nutr. Physiol., 26, 79, 2017.

Nordheim, J. P. and Coon, C. N.: A comparison of four methods for determining available lysine in animal protein meals, Poult. Sci., 63, 1040-1051, 1984.

Nörenberg, P.: Untersuchungen zum maximalen Stickstoffretentionsvermögen wachsender weiblicher Schweine, Diss. Univ. Leipzig, Leipzig, 1987.

Osborne, T. B., Mendel, L. B., and Ferry, E. L.: A method of expressing numerically the growth promoting value of proteins, J. Biol. Chem., 37, 223-229, 1919. 
Oser, B. L.: Method of Integrating Essential Amino Acid Content in the Nutritional Evaluation of Protein, J. Am. Diet. Assoc., 27, 396-402, 1951.

Pastor, A.: Aminosäurenwirksamkeit beim Mastgeflügel unter spezifischer Betrachtung der verzweigtkettigen Aminosäuren, Diss. Univ. Göttingen, 321 pp., http://hdl.handle.net/11858/ 00-1735-0000-0022-5E64F (last access: August 2017), 2014.

Pastor, A., Wecke, C., and Liebert, F.: Assessing the age dependent optimal dietary branched-chain amino acid ratio in growing chicken by application of a non-linear modeling procedure, Poult. Sci., 92, 3184-3195, 2013.

Peres, H. and Olivia-Teles, A.: The effect of dietary protein replacement by crystalline amino acid on growth and nitrogen utilization of turbot Scophthalmus maximus juveniles, Aquaculture, 250, 755-764, 2005.

Piccolo, G., Iaconisi, V., Marono, S., Gasco, L., Loponte, R., Nizza, S., Bovera, F., and Parisi, G.: Effect of Tenebrio molitor larvae meal on growth performance, in vivo nutrients digestibility, somatic and marketable indexes of gilthead sea bream (Sparus aurata), Anim. Feed Sci. Technol., 226, 12-20, 2017.

Ravindran, V., Adeola, O., Rodehutscord, M., Kluth, H., van der Klis, J. D., van Eerden, E., and Helmbrecht, A.: Determination of ileal digestibility of amino acids in raw materials for broiler chickens - Results of collaborative studies and assay recommendations, Anim. Feed Sci. Technol., 225, 62-72, 2017.

Rutherford, M. S. and Moughan, P. J.: The rat as a model animal for the growing pig in determining ileal amino acid digestibility in soya and milk proteins, J. Anim. Physiol. Anim. Nutr., 87, 292$300,2003$.

Samadi and Liebert, F.: Modelling of threonine requirement in fast growing chickens depending on age, sex, protein deposition and dietary threonine efficiency, Poult. Sci., 85, 1961-1968, 2006 a.

Samadi and Liebert, F.: Estimation of nitrogen maintenance requirements and potential for nitrogen deposition in fast-growing chickens depending on age and sex, Poult. Sci., 85, 1421-1429, 2006 b.

Samadi and Liebert, F.: Threonine requirement of slow-growing male chickens depends on age and dietary efficiency of threonine utilization, Poult. Sci., 86, 1140-1148, 2007a.

Samadi and Liebert, F.: Lysine requirement of fast growing chickens - Effects of age, sex, level of protein deposition and dietary lysine efficiency, J. Poult. Sci., 44, 63-72, $2007 \mathrm{~b}$.

Samadi and Liebert, F.: Modelling the optimal lysine to threonine ratio in growing chickens depending on age and efficiency of dietary amino acid utilisation, Br. Poult. Sci., 49, 45-54, 2008.

Samadi, Wecke, C., Pastor, A., and Liebert, F.: Assessing lysine requirement of growing chicken by direct comparison between supplementation technique and "Goettingen approach", Open J. Anim. Sci., 7, 56-69, 2017.

Sauer, W. C. and Ozimek, L.: Digestibility of amino acids in swine: Results and their practical applications. A review, Livest. Prod. Sci., 15, 367-388, 1986.

Savoie, L. and Gauthier, S. F.: Dialysis cell for the in vitro measurement of protein digestibility, J. Food Sci., 51, 494-498, 1986.
Shen, Y. B., Weaver, A. C., and Kim, S. W.: Effect of feed grade 1-methionine on growth performance and gut health in nursery pigs compared with conventional dl-methionine, J. Anim. Sci., 92, 5530-5539, 2014.

Slawski, H., Adem, H., Tressel, R.-P., Wysujack, K., Koops, U., Wuertz, S., and Schulz, C.: Replacement of fishmeal with rapeseed protein concentrate in diets fed to wels catfish (Silurus glanis L.), Aquacult. Nutr., 17, 605-612, 2011.

Stein, H. H., Pedersen, C., Wirt, A. R., and Bohlke, R. A.: Additivity of values for apparent and standardized ileal digestibility of AA in mixed diets fed to growing pigs, J. Anim. Sci., 83, 2387-2395, 2005.

Stein, H. H., Seve, B., Fuller, M. F., Moughan, P. J. and de Lange, C. F. M.: Invited review: Amino acid bioavailability and digestibility in pig feed ingredients: Terminology and application, J. Anim. Sci., 85, 172-180, 2007.

Thong, H. T. and Liebert, F.: Potential for protein deposition and threonine requirement of modern genotype barrows fed graded levels of protein threonine as the limiting amino acid, J. Anim. Physiol. Anim. Nutr., 88, 196-203, 2004a.

Thong, H. T. and Liebert, F.: Amino acid requirement of growing pigs depending on efficiency of amino acid utilisation and level of protein deposition. 1. Lysine, Arch. Anim. Nutr., 58, 69-88, 2004b.

Thong, H. T. and Liebert, F.: Amino acid requirement of growing pigs depending on efficiency of amino acid utilisation and level of protein deposition. 2. Threonine, Arch. Anim. Nutr., 58, 157168, 2004c.

Van Kempen, T. and Bodin, J.: Near-infrared reflectance spectroscopy (NIRS) appears to be superior to nitrogen-based regression as a rapid tool in predicting the poultry digestible amino acid content of commonly used feedstuffs, Anim. Feed Sci. Technol., 76, 139-147, 1998.

Van Leeuwen, P., Sauer, W. C., Huisman, J., van Weerden, E. J., van Kleef, D., and den Hartog, L. A.: Methodological aspects for the determination of amino acid digestibilities in pigs fitted with ileocecal re-entrant cannulas, J. Anim. Physiol. Anim. Nutr., 58, 122-133, 1987.

von Bertalanffy, L.: Theoretische Biologie, in: 2. Bd., Stoffwechsel, Wachstum, A. Francke AG Verlag, Bern, 1951.

Wecke, C. and Liebert, F.: Lysine requirement studies in modern genotype barrows dependent on age, protein deposition and dietary lysine efficiency, J. Anim. Physiol. Anim. Nutr., 93, 295304, 2009.

Wecke, C. and Liebert, F.: Optimal dietary lysine to threonine ratio in pigs (30-110 kg BW) derived from observed dietary amino acid efficiency, J. Anim. Physiol. Anim. Nutr., 94, E277-E285, 2010.

Wecke, C. and Liebert, F.: Improving the reliability of optimal infeed amino acid ratios based on individual amino acid efficiency data from $\mathrm{N}$ balance studies in growing chicken, Animals, 3, 558-573, 2013.

Wecke, C., Pastor, A., and Liebert, F.: Validation of the lysine requirement as reference amino acid for ideal in-feed amino acid ratios in modern fast growing meat-type chickens, Open J. Anim. Sci., 6, 185-194, 2016. 